\title{
A Policy Rule for the Liberalization of Agriculture in Sri Lanka
}

\author{
Dr. H. N. Thenuwara
}

\begin{abstract}
Economic liberalization enhances the productivity and efficiency of productive resources of a country to the extent that the economy has room to grow. In high growth and developed countries the contribution of agriculture to the per capita income has decreased with increasing per capita income in recent decades. In Sri Lanka, the productivity in the agriculture sector has been negative, while industry and services sectors have contributed positively. This paper argues that liberalization of agriculture by way of lower tariff barriers may not result in productive gains in the sector, but that may incur serious losses arising from political economy dimensions. The paper also shows that the continuing phenomenon of falling global commodity prices may result in endogenous generation of price competition in agriculture sector, that may replace any exogenous tariff reductions intended for ensuring price competition, provided non-tariff barriers are removed. Liberalization of industry and services sectors may also bring in pressure on agriculture sector by way of wage increases which force agriculture sector to become competitive. Thus, an optimal policy for the liberalization of agriculture is to remove all non-tariff barriers while maintaining tariff and para-tariff barriers at fixed levels to allow the evolution of endogenous price competition which may eliminate costs arising from political economy dimensions. (JEL F13, 013)
\end{abstract}

\section{Introduction}

Agriculture assumes an important place in a country. Agriculture is often discussed with passion and emotional attachment with overwhelming power to overturn any economic arguments for liberalization. Economic liberalization allows countries to develop productive sectors while allowing creative 
destruction of unproductive sectors. In sectors where emotional attachments are strong, such destruction seems brutal. Such perceptions could generate costs offsetting benefits from liberalization. Thus, agriculture has assumed a central role in strategic political plans in both developed and developing countries. There could be serious economic and social costs if agricultural policies are not handled prudently. Taking above into consideration, this paper recommends a policy rule for the liberalization of agriculture in Sri Lanka. The rest of the paper is structured as follows. Part II explains role of agriculture in economic growth of countries. Extent of technological progress in agriculture and the impact on agriculture through terms of trade effect are discussed in Part III. Part IV explains political economy aspects, and Part V concludes with policy prescription and justification.

\section{Role of Agriculture in Economic Growth}

Global production (value added) of agriculture increased at 2 percent per annum from 1977 to 1996, a rate lower than the growth rate of global Gross Domestic Product (GDP). ${ }^{1}$ Global GDP grew at 5.1 percent during this period. As a result, the share of agriculture in GDP declined gradually from 7.8 percent in 1977 to 4.3 percent in 1996 (Table 1). The share declined in countries in all income categories; high, middle and low. In 1996 the shares in those countries were 2, 12 and 29 respectively.

Table 1 - Share of Agriculture in GDP

\begin{tabular}{|c|c|c|c|c|c|c|c|c|c|}
\hline Year & World & $\begin{array}{c}\text { High } \\
\text { Income } \\
\text { Countries }\end{array}$ & $\begin{array}{l}\text { Middle } \\
\text { Income } \\
\text { Countries }\end{array}$ & $\begin{array}{c}\text { Low } \\
\text { Income } \\
\text { Countries }\end{array}$ & Year & World & $\begin{array}{c}\text { High } \\
\text { Income } \\
\text { Countries }\end{array}$ & $\begin{array}{l}\text { Middle } \\
\text { Income } \\
\text { Countrie }\end{array}$ & $\begin{array}{c}\text { Low } \\
\text { Income } \\
\text { Countries }\end{array}$ \\
\hline 1965 & 11.5 & 7.3 & 24.0 & 42.6 & 1981 & 6.6 & 3.8 & 16.3 & 35.1 \\
\hline 1966 & 10.9 & 7.0 & 22.4 & 42.4 & 1982 & 6.5 & 3.6 & 16.0 & 34.5 \\
\hline 1967 & 10.7 & 6.6 & 22.7 & 44.5 & 1983 & 6.3 & 3.3 & 16.3 & 34.9 \\
\hline 1968 & 10.5 & 6.0 & 23.3 & 43.7 & 1984 & 6.3 & 3.4 & 16.2 & 33.7 \\
\hline 1969 & 9.9 & 5.6 & 21.8 & 43.2 & 1985 & 6.0 & 3.3 & 15.5 & 32.9 \\
\hline 1970 & 9.1 & 5.3 & 20.8 & 41.8 & 1986 & 5.9 & 3.1 & 15.4 & 32.2 \\
\hline 1971 & 8.8 & 5.0 & 20.4 & 40.4 & 1987 & 5.9 & 3.0 & 15.3 & 31.8 \\
\hline 1972 & 8.8 & 5.1 & 19.8 & 40.9 & 1988 & 5.7 & 2.9 & 15.0 & 33.2 \\
\hline 1973 & 9.4 & 5.8 & 20.1 & 42.5 & 1989 & 5.8 & 2.9 & 14.6 & 32.0 \\
\hline 1974 & 8.9 & 5.3 & 19.6 & 40.4 & 1990 & 5.6 & 2.8 & 14.4 & 31.7 \\
\hline 1975 & 8.6 & 5.2 & 18.6 & 38.6 & 1991 & 5.0 & 2.5 & 13.3 & 32.0 \\
\hline 1976 & 8.3 & 4.9 & 18.7 & 37.0 & 1992 & 4.7 & 2.4 & 12.2 & 31.3 \\
\hline 1977 & 7.7 & 4.5 & 18.3 & 38.0 & 1993 & 4.5 & 2.2 & 11.7 & 30.9 \\
\hline 1978 & 7.3 & 4.4 & 17.1 & 36.9 & 1994 & 4.6 & 2.2 & 12.0 & 30.7 \\
\hline 1979 & 7.2 & 4.3 & 16.9 & 35.4 & 1995 & 4.4 & 2.1 & 12.0 & 29.2 \\
\hline 1980 & 6.6 & 3.7 & 16.1 & 35.7 & 1996 & 4.3 & 2.0 & 11.6 & 28.9 \\
\hline
\end{tabular}

1/ World Bank (1999) 
The declining share of agriculture in the global economy signals the limitations of agriculture to fuel continuing economic growth. Limitations arise from the nature of the demand for agricultural products, ability to generate new products and innovative ways of production in agriculture sector. Thus, agriculture sharply contrasts with industrial and services sectors' ability to generate new products and innovations, that could enhance consumer demand and firms' supply. Quah (1997) provides a finer analysis where he distinguishes between the ability to fuel up economic growth by 'products with weight' and 'products without weight'. Weightless products are mostly the products of services industry and information technology industry.

Many developed and fast growing countries have experienced rapid expansion in the services sector compared to the agriculture and industrial sectors. The expansion in services sector reflects the evolution of consumer tastes and tools of production. Back in 1857, the German economist Ernst Engel observed that as families grew richer, they allocated a smaller portion of household budget to food. ${ }^{2}$ Engle's law is applicable to a nation as a whole. A nation with growing income would spend increasingly smaller share of that income on food, shelter and other goods with physical manifestation. They demand more and more services to make life more secure and enjoyable. The economy supplies more and more such services to fulfil that demand raising the services sector output.

Expansion in the services sector is also a result of efforts by firms in the agriculture and industrial sectors to raise value and price of their goods. Production of goods in agriculture and industrial sectors are constrained by demand. To secure a better price, producers in those sectors add more features to the goods making them more appealing to consumers. For example, a modern motor car delivers more features such as secure breaks, high quality seating and music than an old car, which are essentially products of service industries.

Experience in developed countries and high growth economies in Asia in recent decades shows that the economic growth and high levels of per capita income have been fuelled by the growth in the services sector. To investigate this claim, overall growth of an economy is divided into sectoral contributions as shown in Quah (1997). According to this decomposition, overall economic growth is the sum of the contribution by the growth in different sectors weighted by the share of each sector's output in the overall GDP. ${ }^{3}$

2/ Federal Reserve Bank of Dallas (1994)

3/ Assume that GDP growth $g$ arises from different sectors. GDP is denoted $Y$ and $j^{\text {th }}$ sector output is denoted $Y_{j}$. Thus,

$$
Y=\sum_{\mathrm{j}} Y_{j} ; g=\frac{\dot{Y}}{Y}=\sum \frac{Y_{j} \dot{Y}_{j}}{Y Y_{j}} ;=\sum \gamma_{j} g_{j}
$$

where $g_{j}$ is the share of the $j^{\text {th }}$ sector and $g_{j}$ is the growth in $j^{\text {th }}$ sector. 
Table 2 - Per Capita Income, GDP Growth and Sectoral Contribution to GDP Growth in Selected Countries

\begin{tabular}{|c|c|c|c|c|c|c|}
\hline \multirow[t]{2}{*}{ Country } & \multirow{2}{*}{$\begin{array}{c}\text { Per Capita } \\
\text { Income in } \\
1997 \\
\text { USD }\end{array}$} & \multirow[t]{2}{*}{$\begin{array}{l}\text { Time } \\
\text { Span }\end{array}$} & \multirow{2}{*}{$\begin{array}{c}\text { GDP } \\
\text { Growth } \\
\text { (percent) }\end{array}$} & \multicolumn{3}{|c|}{$\begin{array}{l}\text { Sectoral Contribution } \\
\text { to the GDP Growth }\end{array}$} \\
\hline & & & & Agriculture & Industry & Services \\
\hline Singapore & 32,810 & $\begin{array}{l}1972-77 \\
1977-82 \\
1982-87 \\
1987-92 \\
1992-97\end{array}$ & $\begin{array}{r}17.7 \\
18.4 \\
5.8 \\
19.6 \\
7.3 \\
\end{array}$ & $\begin{array}{r}1.6 \\
0.5 \\
-1.1 \\
0.0 \\
0.0 \\
\end{array}$ & $\begin{array}{l}35.0 \\
39.4 \\
40.0 \\
35.0 \\
29.2\end{array}$ & $\begin{array}{l}63.4 \\
60.1 \\
61.1 \\
65.0 \\
70.9 \\
\end{array}$ \\
\hline USA & 29,080 & $\begin{array}{l}1972-77 \\
1977-82 \\
1982-87 \\
1987-92 \\
1992-97\end{array}$ & $\begin{array}{r}10.3 \\
9.8 \\
7.4 \\
5.9 \\
2.6\end{array}$ & $\begin{array}{r}-5.0 \\
2.1 \\
0.8 \\
1.8 \\
2.0\end{array}$ & $\begin{array}{l}48.3 \\
30.3 \\
22.1 \\
17.3 \\
33.2\end{array}$ & $\begin{array}{l}56.8 \\
67.6 \\
77.1 \\
81.0 \\
64.8\end{array}$ \\
\hline UK & 20,870 & $\begin{array}{l}1972-77 \\
1977-82 \\
1982-87 \\
1987-92 \\
1992-97\end{array}$ & $\begin{array}{r}9.8 \\
13.1 \\
7.2 \\
9.0 \\
2.5 \\
\end{array}$ & $\begin{array}{l}2.2 \\
2.0 \\
1.0 \\
1.4 \\
2.0\end{array}$ & $\begin{array}{l}39.7 \\
42.1 \\
26.9 \\
21.3 \\
24.5\end{array}$ & $\begin{array}{l}58.1 \\
55.8 \\
72.1 \\
77.3 \\
73.5 \\
\end{array}$ \\
\hline Korea & 10,550 & $\begin{array}{l}1972-77 \\
1977-82 \\
1982-87 \\
1987-92 \\
1992-97\end{array}$ & $\begin{array}{r}28.1 \\
15.3 \\
12.5 \\
17.7 \\
5.9\end{array}$ & $\begin{array}{r}20.3 \\
6.7 \\
5.0 \\
5.3 \\
18.7\end{array}$ & $\begin{array}{l}39.4 \\
43.7 \\
47.3 \\
45.4 \\
25.0\end{array}$ & $\begin{array}{l}40.4 \\
49.6 \\
47.8 \\
49.2 \\
56.3 \\
\end{array}$ \\
\hline Philippines & 1,200 & $\begin{array}{l}1972-77 \\
1977-82 \\
1982-87 \\
1987-92 \\
1992-97\end{array}$ & $\begin{array}{r}19.6 \\
13.6 \\
-2.2 \\
9.8 \\
3.7 \\
\end{array}$ & $\begin{array}{r}29.0 \\
17.4 \\
18.0 \\
17.6 \\
6.6 \\
\end{array}$ & $\begin{array}{l}38.4 \\
41.9 \\
75.5 \\
30.6 \\
23.7 \\
\end{array}$ & $\begin{array}{r}32.6 \\
40.7 \\
6.4 \\
51.7 \\
70.2 \\
\end{array}$ \\
\hline Sri Lanka & 800 & $\begin{array}{l}1972-77 \\
1977-82 \\
1982-87 \\
1987-92 \\
1992-97 \\
\end{array}$ & $\begin{array}{l}2.5 \\
5.2 \\
3.8 \\
3.1 \\
4.3\end{array}$ & $\begin{array}{r}10.6 \\
19.7 \\
21.0 \\
16.3 \\
6.1 \\
\end{array}$ & $\begin{array}{l}27.8 \\
32.6 \\
23.0 \\
33.0 \\
41.9\end{array}$ & $\begin{array}{l}62.0 \\
48.3 \\
56.1 \\
50.8 \\
52.2 \\
\end{array}$ \\
\hline Pakistan & 500 & $\begin{array}{l}1972-77 \\
1977-82 \\
1982-87 \\
1987-92 \\
1992-97\end{array}$ & $\begin{array}{r}10.2 \\
15.0 \\
1.6 \\
7.7 \\
2.5\end{array}$ & $\begin{array}{r}25.0 \\
29.9 \\
-35.3 \\
26.0 \\
18.7\end{array}$ & $\begin{array}{l}25.4 \\
22.2 \\
43.8 \\
28.8 \\
25.0\end{array}$ & $\begin{array}{l}49.6 \\
47.9 \\
91.5 \\
45.2 \\
56.3\end{array}$ \\
\hline
\end{tabular}

Sources: Quah (1999) and the author 
Table 2 shows the relative contribution from different sectors to the overall growth of GDP in a group of selected countries. The table shows that agriculture contributed to GDP growth significantly less than the services sector in those economies. The contribution of the services sector has increased since 1972. The decreasing contribution from the agricultural sector has been offset by the increasing contribution from industry and services sectors. Figure 1 shows that per capita GDP is positively associated with the contribution from the services sector.

\section{Figure 1 - Sectoral Contribution from the Services Sector to GDP Growth Selected Countries}

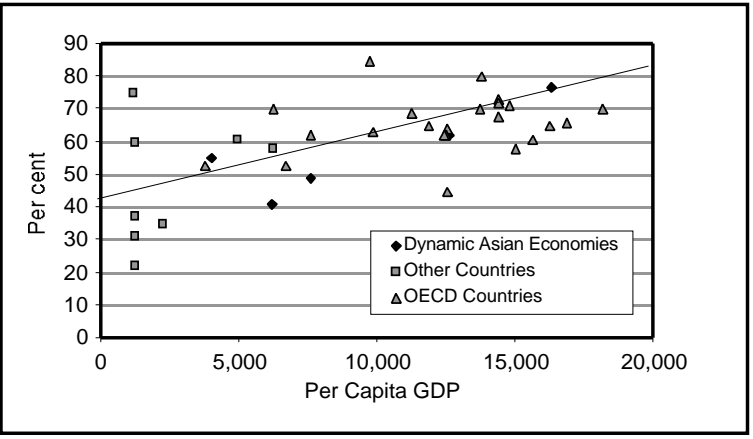

Source - Quah (1997)

Table 3 - Contribution from Agriculture and Services to Per Capita Income Regression Results

Dependent Variable: Per Capita Income

Eq $1 \quad$ Eq $2 \quad$ Eq 3

Constant

$4931.23 \quad 1264.93 \quad 1913.90$

(5.19) (0.66) (0.92)

Contribution from Agriculture

Contribution from Services

$51.09 \quad 45.51$

Standard errors are in parentheses ( )

Table 3 and Figure 2 show the relationships between the contribution by agriculture and services sectors to economic growth, and per capita GDP. 


\section{Figure 2 - Share of Agriculture Vs. GDP Growth - Cross Country Data}

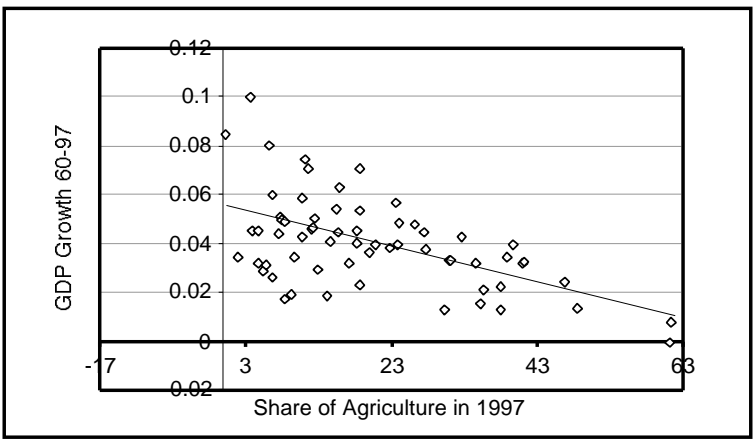

Agriculture sector has shown a strong negative relationship with per capita GDP, whereas services sector has shown a strong positive relationship with per capita GDP.

\section{A. Agriculture Prices}

Agricultural and other commodity prices continued to fall throughout the last century relative to other goods (World Bank, 2000). This is primarily due to dramatic increases in production, higher productivity and lower production costs from technical innovations, and lower transport costs, as well as limitations in demand for agriculture products. The organized efforts by governments and other organizations could not arrest the declining trend in commodity prices. ${ }^{4}$ An extract of data given in World Bank (2000) is reproduced in Table 4.

\section{Extent of Technical Progress and Impact from Terms of Trade}

\section{A. Technological Progress}

Growth of a production sector arises in response to demand for its goods and services. The technology and innovations play a dominant role in increasing supply and lowering the cost of production. Agriculture in Sri Lanka suffers from limitations imposed by both demand and supply.

4/ According to the World Bank (2000), US used to idle crop land to reduce supplies, Brazil initiated the International Coffee Organization in 1962, and petroleum producing countries established the Organization of Petroleum Exporting Countries. The International Cocoa Agreement established in 1972 was abandoned in 1988. The International Natural Rubber Organization collapsed in 1999. 
Table 4 - Global Commodity Prices in Constant 1990 Dollars

\begin{tabular}{|lccccc|}
\hline Commodity & 1970 & 1980 & 1990 & 1998 & 1999 \\
\hline Tea & 332.9 & 230.5 & 205.8 & 196.4 & 177.6 \\
Coconut Oil & 1583.7 & 936.1 & 336.5 & 631.5 & 711.8 \\
Palm Oil & 1036.9 & 810.9 & 289.8 & 644.1 & 421.0 \\
Rice & 503.6 & 570.6 & 270.9 & 291.9 & 239.9 \\
Wheat & 218.9 & 240.0 & 135.5 & 121.1 & 108.2 \\
Sugar & 32.8 & 87.8 & 27.7 & 18.9 & 13.3 \\
Beef & 520.1 & 383.4 & 256.3 & 165.6 & 178.0 \\
\hline
\end{tabular}

Source : World Bank (2000)

Limitations on demand arise from the nature of agricultural products. In Sri Lanka Engel's Law is clearly in operation. Expenditure patterns on food, and all goods and services illustrated in Figure 3 show that as a person grows richer her share of expenditure on food and other goods decline and consumption of services increases sharply. Thus, a higher income cannot generate a strong demand for agriculture products.

The technological improvement in a sector can be evaluated using Solow Residuals. The neo-classical growth model (NCGM) developed by Solow (1956) is assumed to explain the growth of a sector or an economy. The model is based on the following production function.

Figure 3 - Household Expenditure

3a. Share of Expenditure on Food per Person

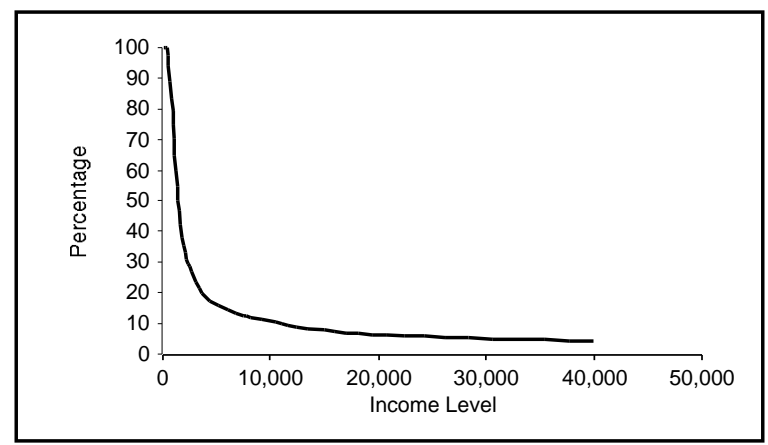




\section{3b. Shares of Expenditure on Goods and Services Incurred by Spending Units} at Different Income Levels

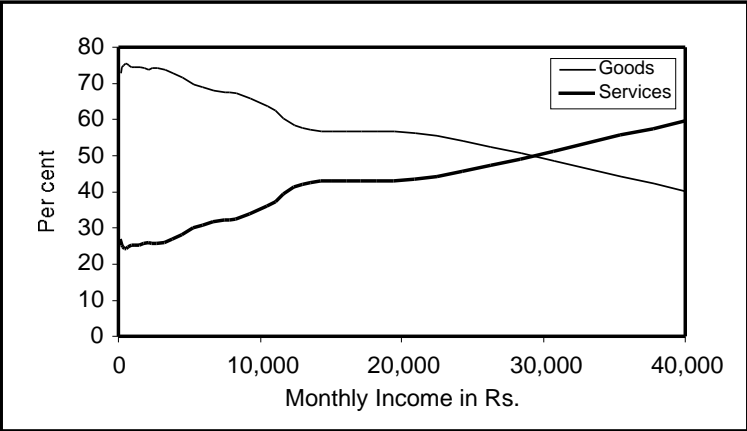

Source: Central Bank of Sri Lanka, Consumer Finance and Socio-Economic Survey Data, 1996/97

$$
Y=A K^{\alpha} L^{1-\alpha}
$$

where, $Y$ is the output, $A$ is the technology, $K$ is the capital stock, $L$ is labour force and $\alpha$ is the intensity of capital. Usually $\alpha$ is calibrated as 0.4 . Thus, the output growth can be written as follows.

$$
\frac{\Delta Y}{Y}=\frac{\Delta A}{A}+\Delta \frac{\Delta K}{K}+(1-\alpha) \frac{\Delta L}{L}
$$

and, the technological progress is given as

$$
\frac{\Delta A}{A}=\frac{\Delta Y}{Y}-\Delta \frac{\Delta K}{K}-(1-\alpha) \frac{\Delta L}{L}
$$

Technological progress in the agricultural sector was estimated using the performance of major agricultural products, paddy, tea, rubber and coconut. Land and labor were taken as major inputs, with the assumption that land plays the role of capital in agriculture. Estimation results are given in Table 5. The technological progress has averaged to -0.1 percent per annum over the period of 1990-1998. This contrasts with productivity growth in the economy as a whole, averaging to 2 percent per annum as shown in Table $6 .^{5}$

5/ In estimating the technological progress, the capital stock of the country was estimated using the investment flows. An annual depreciation of 10 percent was applied on the capital stock. The Technological progress is the Solow Residual which includes developments in technology and human capital. 
Table 5 - Productivity in the Agriculture Sector

\begin{tabular}{|c|c|c|c|c|c|c|c|}
\hline \multirow[b]{2}{*}{ Year } & \multicolumn{3}{|c|}{ Level } & \multicolumn{3}{|c|}{ Growth } & \multirow{2}{*}{$\begin{array}{l}\text { Produc- } \\
\text { tivity } \\
\text { Growth }\end{array}$} \\
\hline & $\begin{array}{l}\text { Labor } \\
\text { Force } \\
(\mathrm{Mn} .)\end{array}$ & $\begin{array}{l}\text { Land } \\
\text { ('000 } \\
\text { hectares }\end{array}$ & $\begin{array}{c}\text { Output } \\
\text { (Rs. Mn. at } \\
1996 \text { prices) }\end{array}$ & Labor & Land & Output & \\
\hline 1990 & 2.36 & 728.14 & $50,495.15$ & & & & \\
\hline 1991 & 2.13 & 736.93 & $47,307.25$ & -0.098 & -0.022 & -0.063 & 0.004 \\
\hline 1992 & 2.09 & 748.19 & $45,011.41$ & -0.019 & -0.016 & -0.049 & -0.031 \\
\hline 1993 & 2.16 & 775.88 & $48,690.64$ & 0.034 & -0.002 & 0.082 & 0.062 \\
\hline 1994 & 2.08 & 815.28 & $52,558.84$ & -0.034 & 0.047 & 0.079 & 0.081 \\
\hline 1995 & 1.97 & 852.12 & $54,637.68$ & -0.057 & -0.001 & 0.040 & 0.074 \\
\hline 1996 & 2.07 & 888.13 & $47,073.00$ & 0.054 & -0.142 & -0.138 & -0.114 \\
\hline 1997 & 2.03 & 929.07 & $50,244.00$ & -0.019 & 0.025 & 0.067 & 0.069 \\
\hline 1998 & 2.68 & 994.09 & $53,641.00$ & 0.321 & 0.099 & 0.068 & -0.164 \\
\hline $\begin{array}{l}\text { Avg. } \\
90-98\end{array}$ & & & & 0.014 & -0.003 & 0.007 & -0.001 \\
\hline
\end{tabular}

Table 6 - Technological Progress in the Economy

\begin{tabular}{|l|ccc|cccc|}
\hline & \multicolumn{3}{|c|}{ Level } & \multicolumn{5}{c|}{ Growth } \\
\cline { 2 - 8 } & $\begin{array}{c}\text { Labour } \\
\text { Force } \\
\text { (Mn.) }\end{array}$ & $\begin{array}{c}\text { Capital } \\
\text { Stock } \\
\text { (Rs.Bn. at } \\
\text { 1996 prices) }\end{array}$ & $\begin{array}{c}\text { Output } \\
\text { (Rs.Bn. at } \\
1996 \\
\text { prices) }\end{array}$ & $\begin{array}{c}\text { Labour } \\
\text { Force }\end{array}$ & $\begin{array}{c}\text { Capital } \\
\text { Stock }\end{array}$ & $\begin{array}{c}\text { Produc- } \\
\text { tion }\end{array}$ & $\begin{array}{c}\text { Produc- } \\
\text { tivity } \\
\text { Growth }\end{array}$ \\
\hline 1990 & 5.05 & 728.14 & 569.54 & & & & \\
1991 & 5.02 & 736.93 & 595.74 & -0.006 & 0.012 & 0.046 & 0.045 \\
1992 & 4.96 & 748.19 & 621.35 & -0.011 & 0.015 & 0.043 & 0.043 \\
1993 & 5.20 & 775.88 & 664.23 & 0.048 & 0.037 & 0.069 & 0.025 \\
1994 & 5.28 & 815.28 & 701.43 & 0.015 & 0.051 & 0.056 & 0.026 \\
1995 & 5.36 & 852.12 & 740.01 & 0.014 & 0.045 & 0.055 & 0.028 \\
1996 & 5.54 & 888.13 & 768.13 & 0.034 & 0.042 & 0.038 & 0.001 \\
1997 & 5.61 & 929.07 & 817.29 & 0.013 & 0.046 & 0.064 & 0.038 \\
1998 & 6.04 & 994.09 & 855.70 & 0.076 & 0.070 & 0.047 & -0.027 \\
\hline Avg. & & & & 0.020 & 0.035 & 0.046 & 0.020 \\
$90-98$ & & & & & & & \\
\hline
\end{tabular}

\section{A. Feedback Effects from the Liberalization of Other Sectors (Terms of Trade Effect)}

Many countries in the world have liberalized non-agriculture sectors to a higher degree than agriculture. In Sri Lanka agriculture has received special 
protection. At present, agricultural products are protected by a high tariff rate of 35 percent, and some important products are also subject to licensing. In the Indo-Lanka Free Trade Agreement, entire agriculture sector has been placed in the 'no-concession category'. ${ }^{6}$ Most non-agriculture products are subject to lower tariff rates, and are free from non-tariff barriers.

The liberalization of some sectors could have an impact on lessliberalized sectors similar to the effects of liberalization. This occurs through the pressure on wages similar to the Balssa-Sameulson effect. ${ }^{7}$ Balssa (1964) and Samuelson (1964) showed that when the productivity in the tradable sector increases product prices and wages will increase in the non-tradable sector. If agriculture is protected, it may not face direct price competition leading to productivity improvements. However, when liberalized sectors face price competition and become increasingly more productive the wages in those sectors will also rise. Thus, the competition for labor and wage bargaining will exert pressure on wages in the agriculture sector. Hence, only the more productive sub-sectors of agriculture could survive in the long run due to those terms of trade effects.

\section{Political Economy Aspects}

\section{A. Sequencing the Liberalization Process}

Some agricultural products in Sri Lanka such as tea, rubber and coconut are operating in rigid labor markets. Organized labor movements enter into wage contracts periodically. Labor retrenchment is made difficult by the strength of labor unions. Thus, some sub sectors in agriculture may have difficulties in facing price competition until the labor market is liberalized and labor laws are relaxed.

\section{B. Popularity and Voter Consent}

The dependence of large rural masses on agriculture and the emotional attachment of the public to national agricultural products have made agricultural policies designed around voter consent. It is conceivable that agricultural policies designed with long-run economic objectives may lead to short-run political problems.

6/ Jayatissa and Thenuwara (2000)

7/ Balassa (1964) and Samuelson (1964) 


\section{International Practices}

Agriculture is generally protected in many countries. The intervention in the agriculture began shortly after World War I. ${ }^{8}$ Agricultural prices in the US rose during the war period due to disturbances to production in Europe. After the production was resumed, prices in the US began to fall. In 1929 the US established the Federal Farm Board to stabilize agricultural prices through purchase and storage of excess supplies. However, the Board failed on account of financial constraints during the Great Depression. In 1929, agricultural sector was also granted tariff protection. In 1933, protection reemerged as the Agricultural Adjustment Act (AAA) with a price support program, a production and adjustment program and a loan and storage program. The AAA was later declared illegal, but much of its contents have been preserved in other forms of support programs. Since then the US has intervened in the market for agricultural products to support farmers with price support and financial relief.

Six countries in European Union (EU) in 1957 established the Common Agricultural Policy (CAP). It aimed at maintaining equality between farm and non-farm incomes, a common internal price, a common external tariff, and common financing for the CAP. Those objectives were achieved through import levies, export subsidies, export taxes, and purchase and storage programs.

Similar protection policies are found in other countries. In view of this widespread culture of protection the World Trade Organization (WTO) treats agriculture as a special sector where protection is justified to a certain degree.

\section{Policy Prescription and Justification}

Sectoral liberalization is achieved through the removal of trade barriers such as tariff, non-tariff and para-tariff. Tariff barriers are taxes imposed on trade. Non-tariff barriers are restrictions imposed on trade such as quotas and licensing. Para-tariff barriers are other charges such as exercise duty, and defence levy. The liberalization policy could be a plan for imposing certain levels of tariff, non-tariff and para-tariff barriers.

There are many economic arguments for not imposing any non-tariff barriers. Non-tariff barriers preclude any imports coming into a country and could grant absolute protection to domestic products, while tariff and

8/ As reported in World Bank (2000). The primary source is a background paper prepared by Prof. Dale E. Hathaway, Director of the National Center for Food and Agriculture Policy. The paper is entitled 'Government Intervention and Commodity Price Stabilization: An Overview of the 20th Century'. 
para-tariff barriers cannot grant absolute protection. Absolute protection cultivates inefficiencies indefinitely. In view of this, at the Uruguay Round Agreements of the WTO it was decided to convert non-tariff barriers to tariff. ${ }^{9}$ Thus, gradual abolition of non-tariff barriers should be an integral part of any liberalization policy.

Governments use para-tariff barriers as revenue raising means. Paratariff should not discriminate against types of products. Discriminatory treatment is usually found in the imposition of tariff.

The optimum tariff policy should derive endogenous price competition rather than imposing price competition by removing tariff, to avoid costs arising from political unrest. Endogenous price competition is derived by freezing tariffs at existing levels and allowing changes in the external environment to generate pressure on prices.

Thus, the optimum policy is to remove all non-tariff barriers, and to freeze tariffs at existing levels with regard to agricultural products, and maintain the consistency of para-tariff barriers across all products.

Removal of non-tariff barriers will ensure that agricultural products are subject to international market pressures when international prices fall below the protection granted. Freezing of tariffs will contain any unrest due to possible intervention in tariffs.

Low growth of productivity in the agriculture sector indicates that the sector either does not contain room for further growth or that it has not been subject to sufficient competition to derive higher productivity gains. Demand constraints and the international experience discussed in the paper indicate that agriculture sector cannot produce growth required to propel the country to a higher level of development. If there are any gains, those may be realized through endogenous price competition.

9/ The process is called tariffication. 


\section{$\underline{\text { References }}$}

Balassa, Bela, 1964, The Purchasing Power Parity Doctrine: A Reappraisal, Journal of Political Economy, 72, pp 585-596.

Federal Reserve Bank of Dallas, (1994), The Service Sector; Give It Some Respect, Annual Report, Dallas.

Jayatissa R. A., and Thenuwara, H. N., (2000), An Evaluation of the Impact of Indo-Lanka Free Trade Agreement on Sri Lanka's Trade and Industry, Staff Studies, Vol. 25-26, Nos. 1 and 2, 1995-96, Published 2000, Central Bank of Sri Lanka.

Quah D., 1997, Increasingly Weightless Economies, Bank of England Quarterly, Vol. 37, No. 1.

Samuelson, P., 1964, Theoretical Notes on Trade Problems, Reviews of Economics and Statistics, 46, pp145-154.

Solow, Robert, 1956, "A Contribution to the Theory of Economic Growth", Quarterly Journal of Economics, 32, 65-94.

World Bank, 1999, World Development Report, The World Bank.

World Bank, 2000, Global Commodity Markets, Number 1, The World Bank. 